\title{
Mollusc shell periostracum as an alternative to tissue in isotopic studies
}

\author{
Michael D. Delong ${ }^{1}$ and James H. Thorp ${ }^{2}$ \\ ${ }^{1}$ Large River Studies Center and Biology Department, Winona State University, Winona, MN, USA \\ ${ }^{2}$ Kansas Biological Survey and Department of Ecology and Evolutionary Biology, University of Kansas, Lawrence, KS, USA
}

\begin{abstract}
Recent studies have used carbon and nitrogen stable isotope ratios of preserved soft tissues to examine historical changes in trophic patterns of aquatic ecosystems. A limitation in this application is the difficulty in finding specimens for primary consumers, which can act as a surrogate for basal food sources in determining the trophic status of higher consumers. The availability of preserved soft tissues of invertebrate primary consumers is often limited in museum and archival collections; hard parts such as mollusc shells, however, are often abundant because of their ease of storage. We used stable isotope ratios of carbon and nitrogen to determine if there was a relationship between the isotopic composition of the periostracum of the shell and soft body tissue of freshwater molluscs. We found a significant correlation between (1) periostracum and tissue of freshly collected freshwater mussels, (2) ethanol-preserved adductor muscle tissue and dry-preserved mussels from museum collections, and (3) ethanol-preserved tissue and periostracum of gastropods from museum collections. The predictability of these relationships enhances the capacity to track changes in trophic complexity over time and responses of food webs to natural and anthropogenic environmental perturbations.
\end{abstract}

\section{Introduction}

Recent developments in the use of preserved tissues for stable isotope analysis have expanded the options available for the study of food web ecology. Past concerns were that liquid preservation of tissues would bias samples through the incorporation of lighter carbon of the preservatives or through the extraction of organic molecules (Hobson et al. 1997, Edwards et al. 2002). Continued study has demonstrated, however, that

*Corresponding author: E-mail: mdelong@winona.edu

\section{Acknowledgments}

We thank Leah McIntosh and Lindsey Rice for preparation of samples for analysis; Roxane Bowen, Stable Isotope Mass Spectrometry Lab of North Carolina State University, for determination of isotopic ratios; and Mike Davis, Minnesota Department of Natural Resources, and his field team for assisting with the collection of mussel specimens. Access to museum specimens would not have been possible without the support of Kevin Cummings (Illinois Natural History Survey), G. Thomas Watters (Ohio State University), and Jon Slaught (Bell Museum of Natural History). This paper was improved through the comments of Maeve Lohan and two anonymous reviewers. This project was funded by the U.S. Environmental Protection Agency's (EPA's) Science to Achieve Results (STAR) Program (\#R832442), managed by the EPA's Office of Research and Development, National Center for Environmental Research. This article represents contribution number 2009-01 from the undergraduate research program of the Large River Studies Center. the effects of preservation on the isotopic ratios of tissues are small and predictable and stabilize within 6 months to 2 years in both fish and invertebrates (Sarakinos et al. 2002, Arrington and Winemiller 2003, Vander Zanden et al. 2003, Syväranta et al. 2008). This realization has allowed for the use of museum specimens to examine temporal changes in trophic dynamics in Lake Tahoe in response to the introduction of nonnative species as well as anthropogenic effects in the Everglades and large rivers in the central US (Vander Zanden et al. 2003, Chasar et al. 2005; M.D. Delong and J.H. Thorp, unpublished data).

One way in which museum specimens have been applied is the traditional, but less frequently applied, use of $\delta^{13} \mathrm{C}$ and $\delta^{15} \mathrm{~N}$ in biplots which allow for comparisons of consumers and the determination of consumer-source linkages based on expected levels of fractionation (Chasar et al. 2005). In other studies, museum specimens have been used to determine changes in the trophic position of consumers over time (e.g., Vander Zanden et al. 2003). Trophic position uses the carbon and/or nitrogen stable isotope ratios of primary consumers to ascertain the location of higher consumers in the food web (Vander Zanden and Rasmussen 1999, Post 2002). It is recommended that long-lived invertebrate primary consumers be used for calculating trophic position because the isotopic ratios of their tissues represent resources assimilated over a longer period (Post 2002). 
A limitation of using museum specimens in food web studies is that the availability of samples may restrict the time frame over which comparisons can be made. This is especially true for specimens of primary consumers, particularly aquatic invertebrates, which are often not collected over the broad time scales seen for fish. Molluscs, particularly freshwater bivalves and gastropods, are an exception, but most museums only began to retain preserved mussel tissue in the 1980s, although a few museums have tissues going back to the 1960s. For example, of the seven museums from which we collected mollusc samples for a project examining historical changes in food chain length, only one museum had preserved tissues from the 1960s. Specimens of mollusc shells, on the other hand, can go back to the early 1800s in US collections. Mollusc shells contain an organic matrix, particularly the outer layer or periostracum (Saleuddin and Petit 1983). Moreover, elements used to synthesize the organic molecules of the shell, particularly carbon, originate from dietary sources (Geist et al. 2005), making them a viable alternative to soft tissue for addressing questions pertaining to trophic processes. Fossil and extant mollusc shells have been used for isotopic studies as an indicator of environmental conditions (Tripati et al. 2001, Fry and Allen 2003) and to examine dietary changes over time (O'Donnell et al. 2003).

This study compared the carbon $\left(\delta^{13} \mathrm{C}\right)$ and nitrogen $\left(\delta^{15} \mathrm{~N}\right)$ stable isotope ratios of the periostracum to those of muscle tissue of recently collected freshwater mussels to determine if a strong enough relationship existed to allow periostracum isotopic ratios to be used in place of respirable tissues of living specimens. We also compared the isotopic ratios of preserved bivalve and gastropod tissue to dried shells from museum collections to ascertain the feasibility of using old specimens to understand historical changes in food webs.

\section{Materials and methods}

Living mussel samples-Fifty-two specimens of the mussel Amblema plicata were collected by hand in June 2005 at a depth of $0.2-1.5 \mathrm{~m}$ from the Upper Mississippi River near Alma, WI, USA. Specimens were placed on ice until they could be returned to the laboratory. Tissue samples were removed from the center of the posterior adductor muscle with a scalpel, rinsed, and dried at $60^{\circ} \mathrm{C}$ for $48 \mathrm{~h}$. Mussel shells were washed with distilled water to remove sediments. Periostracum was removed along the ventral margin of each valve by scraping the outside of each shell with a razor blade. This area of the shell was selected because it represents the addition of periostracum from the current year's growth when the sample is removed from between the ventral margin and the growth line closest to the ventral margin. Samples were placed in a drying oven at $60^{\circ} \mathrm{C}$ for $48 \mathrm{~h}$, after which tissue and shell samples were ground into a fine homogeneous powder using a Wig-L-Bug grinding mill (Cresent Dental Co.). Approximately $1.5 \mathrm{mg}$ of ground sample was placed in unsealed silver capsules, and the capsules were placed in an acid-resistant tray. Approximately $15 \mu \mathrm{L}$ distilled water was added to each unsealed capsule to facilitate acidification. The tray and samples were placed in a desiccator containing a Petri dish filled with concentrated $\mathrm{HCl}$ for $48 \mathrm{~h}$ to remove inorganic carbon (Yamamuro and Kayanne 1995). Samples were removed from the desiccator and dried again for $48 \mathrm{~h}$. Capsules were sealed and reweighed after drying. Acidification of samples was deemed necessary because of the potential for the presence of flakes from the inorganic part of the shell and because of the high carbonate content of the Upper Mississippi and Ohio rivers. Samples were shipped to the Analytical Services Laboratory, Stable Isotope Mass Spectrometry Laboratory, North Carolina State University, for determination of carbon $\left(\delta^{13} \mathrm{C}\right)$ and nitrogen $\left(\delta^{15} \mathrm{~N}\right)$ stable isotopic ratios on a Thermo Finnigan DELTA plus mass spectrometer.

Mussel tissue and shell from museums-Tissue and mussels shells were obtained from multiple museums as part of the study to examine historical changes in riverine food webs. Samples were collected from specimens where both tissue and dry shell from the same individual were available. Tissue and shell samples were obtained from four species, Amblema plicta $(n=19)$, Lampsilis cardium $(n=16)$, Ligumia recta $(n=14)$, and Megalonaias nervosa $(n=12)$, that were originally collected from 1965 to 2003. Specimens were obtained from the collections of the Illinois Natural History Survey (Champaign, IL, USA), Bell Museum of Natural History (St. Paul, MN, USA), and the Ohio State University Museum of Biological Diversity (Columbus, OH, USA) and were originally collected from the Upper Mississippi and Ohio rivers. Tissue and shell samples were collected and processed for isotopic analysis in the same manner described for living specimens, with the exception that living samples were frozen immediately after collection.

Because preservation is known to have a small but predictable effect on isotopic ratios, a pilot study was done to identify the amount of change in the isotopic ratios of mussel tissues preserved in ethanol. The soft tissues of 36 Amblema plicata used for the living mussel component of the tissue-shell relationship were preserved in 70\% ethanol, the most common means of preserving mollusc soft tissues (K. Cummings, personal communication). A sample was extracted from the adductor muscle every 3 months for 1 year. Samples were labeled to reflect the specimen from which it was collected to track changes for each mussel. Samples were prepared as already described for determination of $\delta^{13} \mathrm{C}$ and $\delta^{15} \mathrm{~N}$. Preservation caused a small change of $-0.26 \%$ ( \pm 0.05 $\mathrm{SE})$ in $\delta^{13} \mathrm{C}$ and $-0.23 \%$ ( \pm 0.03$)$ in $\delta^{15} \mathrm{~N}$. Changes in stable isotope ratios were predictable, as in other studies (Sarakinos et al. 2002, Syväranta et al. 2008). These values were then added as a correction factor to the isotopic ratios reported for tissue samples obtained from ethanol-preserved tissues before comparison to shell carbon and nitrogen stable isotope ratios.

Gastropod tissue and shell from museums-Preservation of gastropod tissue in museum collections also rarely dates back any further than the 1980s. Because a small number (total $n=$ 
35) of each of six species were obtained, gastropods were examined collectively to test for relationships in $\delta^{13} \mathrm{C}$ and $\delta^{15} \mathrm{~N}$ of gastropod tissue and periostracum. Specimens were obtained from the collections of the Illinois Natural History Survey (Champaign, IL, USA), and the Ohio State University Museum of Biological Diversity (Columbus, OH, USA) and were originally collected from the Upper Mississippi and Ohio rivers. Shells, whether containing tissue or empty (in the case of the latter, tissue had been removed and stored separately), were placed in a glass vial with $1 \mathrm{~N} \mathrm{HCl}$ to remove the carbonate portion of the shell. It was necessary to remove the old acid and repeat the process several times until all that remained was tissue and periostracum. Tissue and periostracum were removed, washed with distilled water, placed into separate containers, and dried at $60^{\circ} \mathrm{C}$ for $48 \mathrm{~h}$. Soft tissues used for determination of carbon and nitrogen stable isotope ratios were obtained by dissecting sections of the body wall. Samples were prepared for isotopic analysis as previously described for mussels.

Statistical analysis-Comparisons of isotopic ratios of soft tissue and shell for both recent and museum specimens were made separately by linear regression using the PROC GLM procedure of SAS version 9.1. Carbon isotope ratios of shell and tissue of live-collected specimens did not satisfy the assumptions of linear regression without transformation. Carbon isotopes of shell and tissue of live-collected specimens were transformed by $\log _{10}\left(\left(\left|\delta^{13} C_{\min }\right|+1\right)-\delta^{13} C_{\chi}\right)$, where $\left|\delta^{13} C_{\min }\right|$ is the absolute value of the lowest (most negative) observed carbon isotope ratio for shell or tissue and $\delta^{13} C_{x}$ is the carbon isotope ratio for an individual sample. In this situation, the lowest $\delta^{13} \mathrm{C}$ for shell was $-31.6 \%$ and the lowest value for soft tissue was $-31.2 \%$. Data for shell $\delta^{13} \mathrm{C}$, therefore, were corrected by subtracting each observed measure $\left(\delta^{13} C_{x}\right)$ from $(|-31.6|+1)$, whereas the $\delta^{13} \mathrm{C}$ of soft tissue was transformed by taking the difference of each observation and $(|-31.2|+1)$.

Studies on the effects of preservation on the stable isotope ratios of animal tissues have used the difference in carbon and nitrogen isotope ratios of tissues before and after preservation to determine a correction factor (Sarakinos et al. 2002, Vander Zanden et al. 2003). Following along these lines, we took the difference between the carbon and nitrogen isotope ratios of the shell of each sample and subtracted the isotopic ratios of the soft tissue of the same sample. This approach provides another option, separate from the regression results, for correcting $\delta^{13} \mathrm{C}$ and $\delta^{15} \mathrm{~N}$ of shell to values representative of tissue $\delta^{13} \mathrm{C}$ and $\delta^{15} \mathrm{~N}$. This procedure was performed for fresh-collected mussels, mussels obtained from museum specimens, and gastropods obtained from museums.

\section{Assessment}

Mussels-A significant linear relationship was observed for $\delta^{13} \mathrm{C}\left(F=45.13 ; P<0.001 ; R^{2}=0.474\right)$ and $\delta^{15} \mathrm{~N}(F=225.93 ; P<$ $\left.0.001 ; R^{2}=0.819\right)$ between mussel shell and soft tissue from freshly collected specimens (Fig. 1). Results were similar for regression comparison of soft tissue and shell $\delta^{13} \mathrm{C}$ and $\delta^{15} \mathrm{~N}$ of specimens obtained from museum collections (Fig. 2). There was a significant linear relationship for both $\delta^{13} \mathrm{C}(F=48.61$; $\left.P<0.001 ; R^{2}=0.452\right)$ and $\delta^{15} \mathrm{~N}\left(F=169.03 ; P<0.001 ; R^{2}=\right.$ $0.741)$ when preserved soft tissues were compared with shells stored dry in museum cabinets.

The $\delta^{15} \mathrm{~N}$ of tissue, based on the difference between tissue and shell isotopic ratios of individual shells, was consistently greater than that of shell with a mean difference $( \pm 1 \mathrm{SE})$ of $2.52 \%$ o \pm 0.087 . Tissue, in contrast, was typically more ${ }^{13} \mathrm{C}$ depleted than periostracum $(-0.21 \% \pm 0.15)$. The mean difference in $\delta^{15} \mathrm{~N}$ of tissue to shell of museum specimens was similar to that of freshly collected specimens $(2.51 \% \pm 0.15)$,
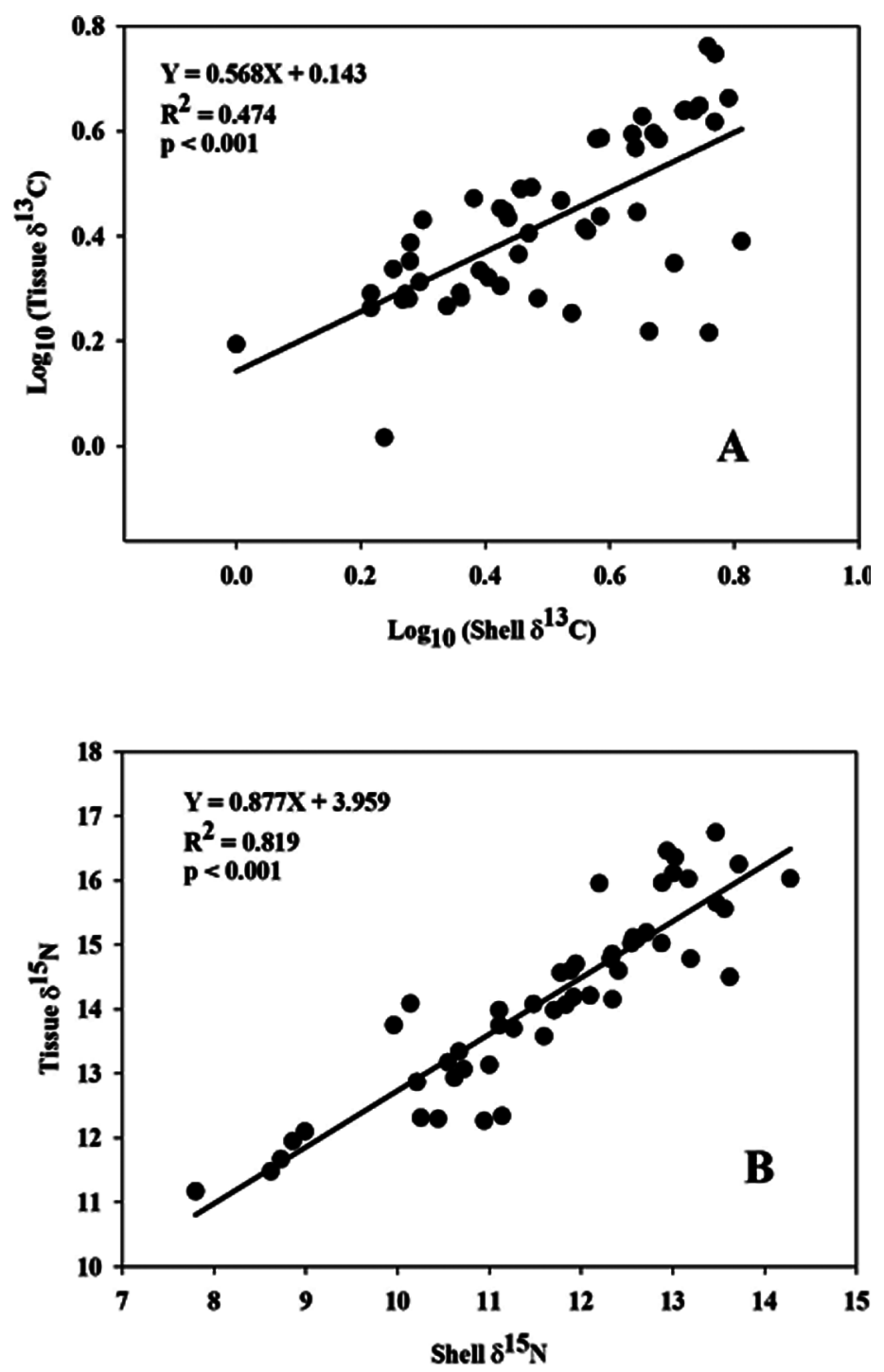

Fig. 1. Relationship between $\delta^{13} \mathrm{C}(\mathrm{A})$ and $\delta^{15} \mathrm{~N}(\mathrm{~B})$ of adductor muscle tissue and periostracum of fresh specimens of the freshwater mussel Amblema plicata (Mollusca: Bivalvia). All specimens were collected live from the Upper Mississippi River near Alma, WI, USA, June $2005(n=52)$. 

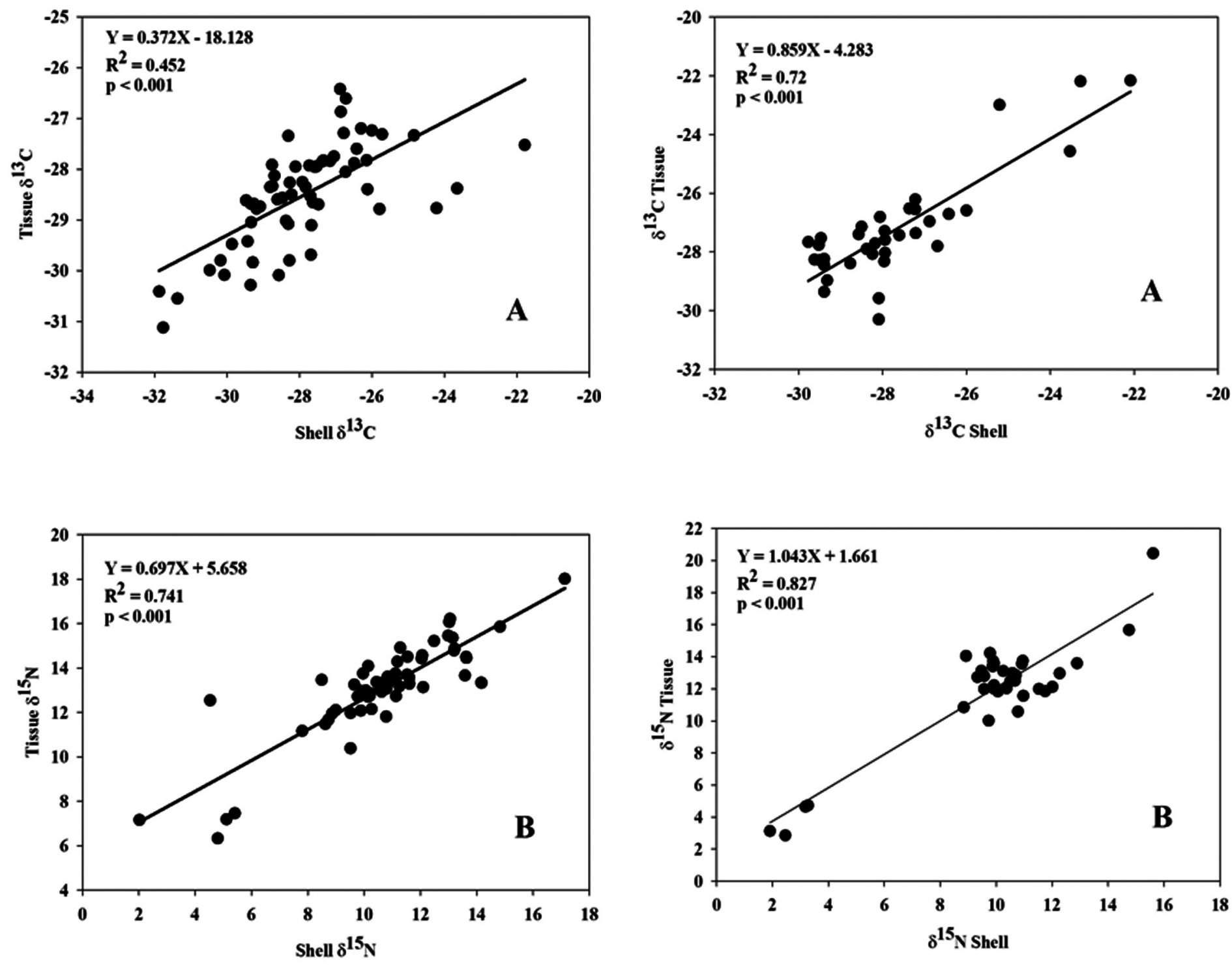

Fig. 2. Relationship between $\delta^{13} \mathrm{C}(\mathrm{A})$ and $\delta^{15} \mathrm{~N}(\mathrm{~B})$ of adductor muscle tissue and periostracum of museum-collected freshwater mussels. Preserved tissue and dried shell of four species were used in the analysis ( $n=$ 61 ). Data for tissue samples were corrected for the effects of preservation before analysis.

but the difference in $\delta^{13} \mathrm{C}$ was somewhat higher for museum specimens $(-0.44 \% \pm 0.11)$. These differences can be used to correct shell $\delta^{13} \mathrm{C}$ and $\delta^{15} \mathrm{~N}$ to tissue $\delta^{13} \mathrm{C}$ and $\delta^{15} \mathrm{~N}$ just as a correction factor has been applied to correct for preservation effects (e.g., Vander Zanden et al. 2003).

Gastropods-There was a significant linear relationship between the periostracum of gastropod shells and soft tissue for $\delta^{13} \mathrm{C}\left(F=85.08 ; P<0.001 ; R^{2}=0.72\right)$ and $\delta^{15} \mathrm{~N}(F=157.95$; $P<0.001 ; R^{2}=0.827$ ) (Fig. 3 ). Differences in gastropod tissue and periostracum isotopic ratios were slightly smaller, when compared to differences for freshwater mussels, for $\delta^{15} \mathrm{~N}$ (2.08\% \pm 0.23$)$. Differences created by subtracting carbon and nitrogen isotope ratios of periostracum from tissue for each

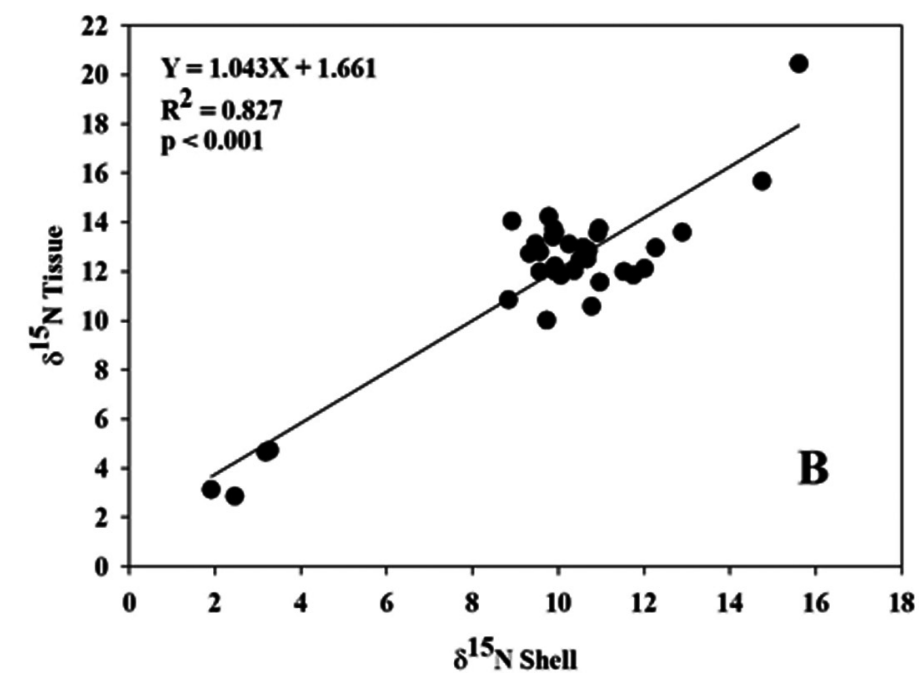

Fig. 3. Relationship between $\delta^{13} \mathrm{C}(\mathrm{A})$ and $\delta^{15} \mathrm{~N}(\mathrm{~B})$ of adductor muscle tissue and periostracum of museum-collected snails (Mollusca: Gastropoda; $n=35$ ). Data for tissue samples were corrected for the effects of preservation before analysis.

gastropod sample revealed that gastropod tissue $\delta^{13} \mathrm{C}$, in contrast to bivalves, was more ${ }^{13} \mathrm{C}$-enriched than gastropod periostracum $(0.44 \%$ \pm 0.16$)$.

\section{Discussion}

Carbon and nitrogen stable isotope ratios for both fresh and preserved adductor muscle tissue of freshwater mussels were heavier than shell periostracum. The same pattern was observed for the marine bivalve Mercanaria mercenaria (O'Donnell et al. 2003). Differences in $\delta^{13} \mathrm{C}$ and $\delta^{15} \mathrm{~N}$ between tissue and shell of $M$. mercenaria were smaller $(0.1 \%$ and $0.7 \%$, respectively) than those observed in our study, but the discrepancy is likely a result of differences in habitat, type of tissue, and shell structure. 
O'Donnell et al. (2003) stated that the origin of differences in the isotopic ratios of shell and tissue are uncertain but may be related to small differences in the isotopic composition of shell proteins or isotopic effects created by differences in resources used in synthesis or shell versus soft tissues. Shell proteins are dominated by a small number of amino acids, such as proline, valine, glycine, aspartate, alanine, and lysine (Zhao and Waite 2005, Marie et al. 2007), all of which, except lysine, do not have nitrogen in their R-group. These possible options may also explain the difference in $\delta^{15} \mathrm{~N}$ of gastropod periostracum and soft tissue. The difference in $\delta^{13} \mathrm{C}$ of the periostracum of gastropods relative to the periostracum of bivalves is difficult to explain given the limited amount of information on the chemistry of gastropod periostracum. Periostracum synthesis does occur in different sites on the mantle of gastropods and bivalves (Saleuddin and Petit 1983), which could account for the contradictory trends observed in shell-tissue $\delta^{13} \mathrm{C}$ comparisons within mussels and gastropods.

Predictability in the changes of tissue isotopic ratios created by preservation is the primary reason the use of soft tissues stored in ethanol or formalin has become an acceptable methodology in ecological studies. Our study has demonstrated that there is also a predictable relationship between the isotopic ratios of the periostracum and muscle tissues of freshwater bivalves and gastropods. Many members of both groups are relatively long-lived species. The isotopic ratios of their tissues, therefore, constitute a greater temporal span of their assimilated diet because of slower rates of tissue turnover. As such, they represent a suitable surrogate for more temporally variable basal resources when investigating the trophic dynamics of aquatic ecosystems (Post 2002). Use of nitrogen isotopic ratios of mollusc shells instead of relying on less commonly available preserved soft tissues expands opportunities for examining historical patterns in food chain length. Carbon and nitrogen isotopic ratios of fossil mollusc shells have effectively been applied in the study of changes in links between primary consumers and basal resources (O'Donnell et al. 2003). Use of more geologically recent shells in combination with preserved tissues of higher consumers would allow for a retrospective analysis of natural and anthropogenic actions on the functional attributes of aquatic ecosystems as well as possible applications, at least with gastropods, in terrestrial systems.

Use of the isotopic ratios of mussel shell in lieu of tissue is also advantageous in the study of modern systems. Freshwater mussels have historically represented a major part of the biomass in aquatic ecosystems. Changes in water quality and habitat loss, however, have made many species a target of conservation efforts as a result of declining densities and local to widespread species loss (Neves 1999, Box and Kershner 2004, Perez-Quintero 2007). Use of shell in lieu of soft tissue makes it possible, therefore, to take a nondestructive approach in the use of mussels in trophic studies or other areas of study where chemical characteristics of mussel shell provide an ecological archive comparable to that of tissues.

\section{Comments and recommendations}

The relationship between $\delta^{13} \mathrm{C}$ of shell and soft tissue of mussels was significant but was not a strong $\left(R^{2}<0.5\right)$ linear relationship. Examination of the data indicated that there were some samples where $\delta^{13} \mathrm{C}$ of shell was considerably more ${ }^{13} \mathrm{C}$-enriched than the $\delta^{13} \mathrm{C}$ of soft tissue. A possible reason for this could be that acidification was not of sufficient duration to remove inorganic carbon that flaked off the shell while scraping off periostracum. The inorganic layers of bivalve shell have considerably higher $\delta^{13} \mathrm{C}$. In the case of Dreissena polymorpha, $\delta^{13} \mathrm{C}$ is around -9\% (Fry and Allen 2003); therefore, a small amount of the inorganic fraction of shell in a $1.5-\mathrm{mg}$ sample of shell would be sufficient to raise the value for $\delta^{13} \mathrm{C}$.

We reexamined the relationship of shell and tissue $\delta^{13} \mathrm{C}$ for both the fresh-collected and museum specimens by removing samples where the shell exhibited unusually high $\left({ }^{13} \mathrm{C}\right.$ enriched) carbon stable isotope ratios (five individuals for the fresh-collected mussels and eight individuals for the museum specimens). A repeat of regression analysis without these individuals resulted in a better linear relationship for both freshcollected specimens $\left(R^{2}=0.77 ; y=0.764 x+0.080\right)$ and the museum specimens $\left(R^{2}=0.72 ; y=0.667 x-9.633\right)$. Because the carbon in the inorganic layers of the shell is from inorganic sources, it is critical that samples are thoroughly acidified to remove carbonates of the shell. This is evident in the case of the gastropod shells, where samples had to be immersed in $\mathrm{HCl}$ multiple times to dissolve all of the inorganic layers of the shell. Placing the entire shell in acid was chosen as a better option than grinding gastropod shells and then soaking them in acid because inorganic shell fractions were still visible in vials containing crushed shell even after being repeatedly placed in acid after 5 days.

Carbon isotope ratios are used in food web studies to develop linkages between basal sources and consumers through mixing models. Potential error from using shell isotopic ratios instead of those of soft tissue might be a point of concern. It is advisable that a mixing model be used that considers potential error in the estimation of source contributions to the assimilated diet of consumers (e.g., IsoError; Phillips and Gregg 2001).

This examination on the use of periostracum was performed in preparation for a study of historical changes in the trophic position of fishes in response to anthropogenic disturbance in rivers. This broader study resulted in the collection of specimens from as early as the mid-19th century up to 2005. An immediate realization was that the frequency of the addition of specimens to museum collections was sporadic. Because of this, plus a desire for broader temporal integration of dietary assimilation and to minimize effects of interannual variation in fish, mollusc, and hydrological data, we chose to obtain specimens representative of 5-year intervals. This strategy allowed for the use of samples from different years for the determination of the trophic position of fish, which were collected across similar 
spans of time. This approach also gave us some latitude in the scraping of periostracum from mussel shell. The space between growth lines on mollusc shells, as would be expected, decreases with age. This makes it difficult to precisely remove periostracum from a single year but allows for removing 2-3 years of growth. The amount of and location from which periostracum is removed, therefore, will depend on the time frame that is relevant to the question asked.

Knowing if shells in museum collections were collected from live or dead specimens would also be important if specific time period is of interest. The advantage of shells from mussels collected when they were alive is that the precise years when periostracum was deposited will be known. Shells found in the field empty and added to a museum collection do not afford that luxury; therefore, a broader time frame must be applied for studies addressing temporal patterns. Other areas of the shell may also be used if time is not a critical factor in the study, especially if areas along the ventral margin are damaged or missing. Our comparison of shell and soft tissue of museum specimens used dry stored shells. This would be comparable to the condition of shells found empty in the field that are added to museum collections; therefore, it would be reasonable to use shells from dead mussels as long as appropriate latitude in time period was applied.

\section{References}

Arrington, D. A., and K. O. Winemiller. 2003. Preservation effects on stable isotope analysis of fish muscle. Transact. Am. Fisheries Soc. 131:337-342.

Box, J. B., and J. Kershner. 2004. Freshwater molluscs of the western United States: where are we today, and where are we going? J. Shellfish Res. 23:282.

Chasar, L. C., J. P. Chanton, C. C. Koenig, and F. C. Coleman. 2005. Evaluating the effect of environmental disturbance on the trophic structure of Florida Bay, U.S.A.: multiple stable isotope analyses of contemporary and historical specimens. Limnol. Oceanogr. 50:1059-1072.

Edwards, M. S., T. F. Turner, and Z. D. Sharp. 2002. Short- and long-term effects of fixation and preservation on stable isotope values $\left(\delta^{13} \mathrm{C}, \delta^{15} \mathrm{~N}, \delta^{34} \mathrm{~S}\right)$ of fluid-preserved museum specimens. Copeia 2002:1106-1112.

Fry, B., and Y. C. Allen. 2003. Stable isotopes in zebra mussels as bioindicators of river-watershed linkages. Riv. Res. Applic. 19:683-696.

Geist, J., K. Auerswald, and A. Boom. 2005. Stable carbon isotopes in freshwater mussel shells: environmental record or marker of metabolic activity? Geochim. Cosmochim. Acta 69:3545-3554.

Hobson, K. A., H. L. Gibbs, and M. L. Gloutney. 1997. Preservation of blood and tissue samples for stable-carbon and stable-nitrogen isotope analysis. Can. J. Zool. 75:17201723.

Marie, B., G. Luquet, J. P. De Barros, N. Guichard, S. Morel, G. Alcaraz, L. Bollache, and F. Marin. 2007. The shell matrix of the freshwater mussel Unio pictorum (Paleoheterdonta, Unionoida): involvement of acidic polysaccharides from glycoproteins in nacre mineralization. FEBS J. 274:29332945.

Neves, R. J. 1999. Conservation and commerce: management of freshwater mussel (Bivalvia: Unionoidea) resources in the United States. Malacologia 41:461-474.

O’Donnell, T. H., S. A. Macko, J. Chou, K. L. Davis-Hartten, and J. F. Wehmiller. 2003. Analysis of $\delta^{13} \mathrm{C}, \delta^{15} \mathrm{~N}$, and $\delta^{34} \mathrm{~S}$ in organic matter from the biominerals of modern and fossil Mercenaria spp. Org. Geochem. 34:165-183.

Perez-Quintero, J. C. 2007. Diversity, habitat use and conservation of freshwater molluscs in the lower Guadiana River basin (SW Iberian Peninsula). Aq. Conserv. Mar. Freshw. Ecosys. 17:485-501.

Phillips, D. L., and J. W. Gregg. 2001. Uncertainty in source partitioning using stable isotopes. Oecologia 127:171-179.

Post, D. M. 2002. Using stable isotopes to estimate trophic position: models, methods, and assumptions. Ecology 83:703-718.

Sarakinos, H. C., M. L. Johnson, and M. J. Vander Zanden. 2002. A synthesis of tissue-preservation effects on carbon and nitrogen stable isotope signatures. Can. J. Zool. 80:381387.

Saleuddin, A. S. M., and H. P. Petit. 1983. The mode of formation and the structure of the periostracum. In Saleuddin, A. S. M., and K. M. Wilbur (eds.). Mollusca, vol. 4, Physiology, Part I. New York, Academic Press, p. 199-234.

Syväranta, J., S. Vesala, M. Rask, J. Ruuhijärvi, and R. Jones. 2008. Evaluating the utility of stable isotope analyses of archived freshwater sample materials. Hydrobiologia 600:121-130.

Tripati, A., J. Zachos, L. Marincovich, and K. Bice. 2001. Late Paleocene Arctic coastal climate inferred from molluscan stable and radiogenic isotope ratios. Palaeogeogr. Palaeoclimatol. Palaeoecol. 170:101-113.

Vander Zanden, M. J., and J. B. Rasmussen. 1999. Primary consumer $\delta^{13} \mathrm{C}$ and $\delta^{15} \mathrm{~N}$ and the trophic position of aquatic consumers. Ecology 80:1395-1404.

Vander Zanden, M. J., S. Chandra, B. C. Allen, J. E. Reuter, and C. R. Goldman. 2003. Historical food web structure and restoration of native aquatic communities in the Lake Tahoe (California-Nevada) Basin. Ecosystems 6:274-288.

Yamamuro, M., and H. Kayanne. 1995. Rapid direct determination of organic carbon and nitrogen in carbonate-bearing sediments with a Yanaco MT-5 CHN analyzer. Limnol. Oceanogr. 40:1001-1005.

Zhao, H., and J. H. Waite. 2005. Coating proteins: structure and cross-linking in fp-1 from the green shell mussel Perna canaluculus. Biochemistry 44:15915-15923.

Submitted 19 December 2008 Revised 16 April 2009 Accepted 7 May 2009 